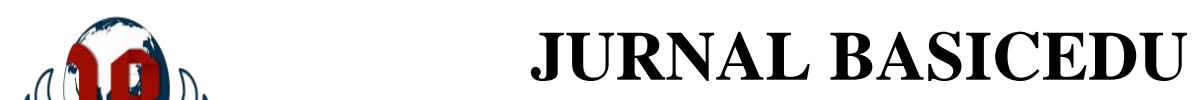

Volume 5 Nomor 3 Tahun 2021 Halaman 1120-1129

Research \& Learning in Elementary Education https://jbasic.org/index.php/basicedu

\title{
Efektivitas Model Problem Based Learning terhadap Kemampuan Pemecahan Masalah Matematika Siswa Sekolah Dasar
}

\author{
Riski Tri Widyastuti ${ }^{1 凶}$, Gamaliel Septian Airlanda ${ }^{2}$ \\ Pogram Studi Pendidikan Guru Sekolah Dasar, Universitas Kristen Satya Wacana, Indonesia ${ }^{1,2}$ \\ E-mail: Riskitriwidyastuti28@gmail.com ${ }^{1}$
}

\begin{abstract}
Abstrak
Model pembelajaran yang termuat dalam kurikulum 2013 salah satunya adalah model pembelajaran berbasis masalah atau Problem Based Learning, kemampuan peserta didik dalam menyelesaikan/memecahkan masalah dianggap masih rendah sehingga diharapkan model pembelajaran PBL mampu meningkatkan kemampuan kemampuan peserta didik dalam aspek kemampuan pemecahan masalah. Tujuan dari penelitian yang telah dilakukan oleh peneliti adalah untuk mengetahui serta mengkaji kembali dampak dari diberlakukannya model pembelajaran berbasis masalah (PBL) jika ditinjau dari kemampuan peserta didik dalam menyelesaikan masalah khususnya matematika. Peneliti dalam melakukan penelitiannya menggunakan metode penelitian deskriptif, yaitu menjabarkan sendiri hasil temuannya berdasarkan 20 jurnal artikel sejenis yang telah dianalisa, hasil analisa kemudian diuraikan secara mandiri oleh peneliti untuk mendapatkan kesimpulannya sendiri. Penelitian ini dilakukan dengan mencari besaran pengaruh (Effect Size) untuk mengetahui dampak diberlakukannya model pembelajaran pembelajaran PBL terhadap kemampuan peserta didik dalam menyelesaikan masalah. Hasil menunjukkan nilai effect size 1,009 dan dapat dilihat dari tabel interpretasi Cohen's bahwa model Pembelajaran Problem Based Learning berpengaruh sangat besar pada pembelajaran matematika Sekolah Dasar, dapat disimpulkan bahwa model pembelajaran berbasis masalah (PBL) memberi dampak yang positif terhadap kemampuan peserta didik dalam menyelesaikan masalah.
\end{abstract}

Kata Kunci: problem based learning, kemampuan pemecahan masalah matematika, siswa sekolah dasar.

\section{Abstract}

One of the learning models included in the 2013 curriculum is Problem Based Learning. Students' problem solving skills is still considered low so that it is expected that the PBL learning model can improve students' problem solving skills. The purpose of the research that has been carried out by researchers is to determine and review the impact of the application of problem-based learning models (PBL) viewed from students' problem solving skills, especially in mathematics subject. The researchers used descriptive research methods in which they described their own findings based on 20 similar journals that have been analyzed, the results of the analysis were then described independently by the researchers to get the conclusions. This research was conducted by looking for the effect size to determine the impact of the implementation of the PBL learning model on students' problem solving skills. The results show the effect size value of 1.009 and it can be seen from Cohen's interpretation table that the Problem Based Learning model has a very large effect on elementary school mathematics learning, it can be concluded that the problem-based learning model (PBL) has a positive impact on students' problem solving skills.

Keywords: problem based learning, mathematic problem solving skills, elementary school students.

Copyright (c) 2021 Riski Tri Widyastuti, Gamaliel Septian Airlanda

Corresponding author :

Email : Riskitriwidyastuti28@gmail.com

DOI : https://doi.org/10.31004/basicedu.v5i3.896

ISSN 2580-3735 (Media Cetak)

ISSN 2580-1147 (Media Online)

Jurnal Basicedu Vol 5 No 3 Tahun 2021

p-ISSN 2580-3735 e-ISSN 2580-1147 
1121 Efektivitas Model Problem Based Learning terhadap Kemampuan Pemecahan Masalah Matematika Siswa Sekolah Dasar - Riski Tri Widyastuti, Gamaliel Septian Airlanda

DOI : https://doi.org/10.31004/basicedu.v5i3.896

\section{PENDAHULUAN}

Pembelajaran adalah hubungan timbal balik antara guru dan siswa guna mewujudkan pendidikan nasional. Pembelajaran bukanlah suatu proses pemindahan pengetahuan yang dimiliki oleh guru kepada siswa, melainkan pengertian dari pembelajaran yaitu suatu kegiatan dimana siswa diberikan kesempatan penuh oleh guru untuk menemukan sendiri ide, konsep maupun gagasan berdasarkan pengetahuan siswa itu sendiri dalam hal ini berarti siswa ikut berpartisipasi secara langsung dalam proses pembelajaran. Sehingga dalam hal ini siswa tidak berperan sebagai seseorang yang pasif melainkan seseorang yang aktif dalam menemukan sendiri ide, konsep serta gagasan baru berdasarkan pengetahuan yang ia miliki dibawah bimbingan guru , guru bertindak sebagai pembimbing serta pengarah siswa dalam mempelajari hal baru. Oleh karena itu, dalam pembelajaran itu sendiri harus dikemas dengan baik sehingga siswa dapat merasakan pengalaman langsung dalam memperoleh ilmu baru termasuk matematika. (KEMENDIKBUD, 2013) tentang standar proses bahwa kurikulum 2013 adalah kurikulum yang menggunakan pendekatan Saintifik dimana isi dalam kurikulum 2013 menyarankan 3 jenis model yaitu : (1) model pembelajaran dengan basis penyingkapan atau penelitian (discovery/inquiry learning), (2) Model pembelajaran dengan berbasiskan masalah (Problem Based Learning), (3) pembelajaran yang menghasilkan suatu produk akhir yang didapatkan dari hasil penyelesaian suatu masalah (Project Based Learning). Berdasarkan uraian diatas terdapat 3 model yang termuat dalam kurikulum 2013 yang diharapkan mampu untuk mewujudkan tujuan pendidikan nasional.

Pembelajaran berbasis masalah (Problem Based Learning) merupakan salah satu model pembelajaran yang termuat dalam kurikulum 2013. (Ejin, 2016) menyatakan bahwa Problem Based Learning adalah salah satu model pembelajaran menghadapkan peserta didik pada masalah di kehidupan nyata yang mereka alami serta masalah yang disajikan bersumber dari kehidupan sehari-hari yang relevan. Sejalan dengan pendapat tersebut (Slameto, 2013) juga memberikan pendapatnya mengenai model pembelajaran Problem Based Learning , Problem Based Learning adalah salah satu model pembelajaran dimana dalam prosesnya memberikan pelatihan dan pengembangan terhadap masalah otentik dari kehidupan aktual siswa guna merangsang kemampuan tingkat tinggi. (Kodariyati \& Astuti, 2016) menjabarkan tahapan/sintaks dari model PBL antara lain : pengenalan peserta didik pada masalah yang menjadi pembahasan, Mengintruksikan peserta didik untuk berpikir, Mengarahkan pemecahan masalah peserta didik baik secara mandiri maupun berkelompok, menyajikan hasil karya , melakukan analisis serta evaluasi proses pemecahan masalah yang telah dilakukan. Berdasarkan pendapat yang telah dikemukakan dapat disimpulkan bahwa Problem Based Learning merupakan salah satu model pembelajaran yang menuntut partisipasi aktif dari siswa, dalam hal ini siswa diberikan kesempatan penuh untuk terjun dan berpartisipasi langsung dalam menggali sendiri pengetahuannya berdasarkan masalah nyata (kontekstual) yang biasa dihadapi dalam kehidupan sehari-hari. Model pembelajaran Problem Based Learning diharapkan mampu membantu siswa untuk terbiasa dalam memecahkan serta menganalisa suatu permasalahan sehingga kemampuan pemecahan masalah siswa akan terbentuk secara maksimal.

(Aqil, 2013) mengutarakan pendapatnya mengenai pengertian dari kemampuan pemecahan masalah , kemampuan yang dimiliki oleh peserta didik dalam menyikapi masalah mulai dari memahami apa yang menjadi pokok masalah, membuat cara/strategi yang dibutuhkan untuk menyelesaikan masalah tersebut serta melakukan strategi yang telah dibuat. Hal ini sejalan dengan pendapat yang diutarakan oleh Polya yang dikutip oleh Ahmad Susanto menguraikan bahwa terdapat 4 langkah dalam memecahkan suatu masalah antara lain mengerti/memahami pokok yang menjadi suatu masalah, membuat rancangan/rencana yang berguna dalam penyelesaian masalah tersebut, memperhitungkan strategi yang telah dibuat dan melaksanakan strateginya dan kemudian langkah terakhir adalah melakukan pemeriksaan proses dan hasil yang telah dilakukan (Susanto, 2014). Pada mata pelajaran matematika terdapat proses pemecahan masalah misalnya saja saat siswa mempelajari cara menghitung volume sebuah kubus, hal pertama yang harus dilakukan siswa 
1122 Efektivitas Model Problem Based Learning terhadap Kemampuan Pemecahan Masalah Matematika Siswa Sekolah Dasar - Riski Tri Widyastuti, Gamaliel Septian Airlanda

DOI : https://doi.org/10.31004/basicedu.v5i3.896

adalah memahami pertanyaan yang ditanyakan lalu kemudian siswa harus memikirkan strategi untuk menjawab pertanyaan tersebut menggunakan logikanya sendiri. Kemampuan pemecahan masalah penting dimiliki oleh seorang peserta didik karena dalam kehidupan sehari-hari peserta didik akan selalu menjumpai yang dinamakan oleh masalah (Ertikanto, 2016) , sehingga dengan adanya perbaikan kurikulum yang kemudian didalam kurikulum tersebut terdapat yang dinamakan dengan model pembelajaran salah satunya model pembelajaran berbasis masalah (PBL). PBL diharapkan mampu untuk meningkatkan kemampuan peserta didik dalam memahami dan menyelesaikan masalah yang dihadapinya.

Penelitian yang telah dilakukan oleh (Nasir, 2016) berjudul "Efektivitas Model Pembelajaran Berbasis Masalah (Problem Based Learning) Terhadap Kemampuan Pemecahan Masalah Siswa Pada Pembelajaran Matematika" yang menunjukan bahwa penerapan model pembelajaran PBL efektif terhadap kemampuan pemecahan masalah matematika siswa SD daripada model konvensional. Penelitian selanjutnya dilakukan oleh (Putri, 2020) yang berjudul "Efektivitas Problem Based Learning dan Problem Solving Ditinjau dari Kemampuan Pemecahan Masalah Matematika Peserta Didik Kelas IV SD" menurut penelitian yang telah dilakukan oleh Putri memberikan hasil yang mengatakan bahwa adanya perbedaan antara kedua jenis model pembelajaran yang dibandingkan, dalam hal ini pada materi pembulatan serta penaksiran 2 bilangan cacah dan pecahan bahwa model pembelajaran berbasis masalah (PBL) lebih baik dan lebih efektif dibandingkan dengan model problem solving. Penelitian yang sama juga dilakukan oleh (Sapoetra, Bagoes Pradana, 2020) yang berjudul "Efektivitas Model Pembelajaran Problem Based Learning Ditinjau dari Kemampuan Pemecahan Masalah Matematika di Sekolah Dasar" dengan hasil penelitiannya yang mengatakan bahwa model pembelajaran berbasis masalah (PBL) memberikan dampak yang cukup efektif pada peserta didik dalam aspek kemampuan penyelesaian/pemecahan masalah khususnya dikelas IV. Berdasarkan penelitian yang telah dilakukan sebelumnya, oleh karena itu peneliti ingin melakukan penelitian tentang "Meta-analisis Efektivitas Model Problem Based Learning Terhadap Kemampuan Pemecahan Masalah Matematika Siswa SD". Peneliti menganalisis artikel ilmiah sebanyak 20 jurnal dengan pokok pembahasan yang sama untuk dicari besaran pengaruh (Effect Size) , berdasarkan hasil perhitungan yang dilakukan oleh peneliti didapatkan hasil effect size sebesar 1,009 yang jika dilihat pada tabel Cohen's $d$ 1,009 artinya berpengaruh sangat besar. Namun melihat kenyataan yang terjadi dalam pendidikan Indonesia, guru masih melakukan kegiatan pembelajaran tradisional dan kurang menguasai tentang model pembelajaran PBL.

\section{METODE PENELITIAN}

Jenis penelitian yang digunakan adalah meta analisis, (Kadir, 2017) Metaanalisis merupakan proses menganalisis hasil penelitian dengan tema dan fokus yang sama yang bersumber dari peneliti terdahulu. Sejalan dengan pendapat tersebut, meta analisis merupakan penelitian yang dilakukan oleh seorang peneliti dengan cara mengumpulkan data penelitian, data yang sudah diperoleh kemudian masuk kedalam proses review dan analisis, data penelitian yang diambil merupakan data yang diperoleh dari para peneliti sebelumnya. (Anugraheni, 2018). Populasi yang digunakan dalam penelitian metaanalisis ini adalah model pembelajaran Problem Based Learning , kemudian dari model pembelajaran tersebut sampel yang diambil adalah bagaimana model pembelajaran berbasis masalah (PBL) memberikan pengaruh kepada kemampuan peserta didik dalam menyelesaikan suatu masalah khususnya matematika. Proses pengumpulan data dilakukan peneliti dengan cara mencari artikel dengan kata kunci penelusuran "Problem Based Learning" dan "kemampuan pemecahan masalah matematika siswa SD" melalui google schoolar maka diperoleh sebanyak 20 artikel yang sejenis. Selanjutnya data yang dihasilkan dari 20 artikel tersebut dihitung untuk mencari besar effect size dari penerapan model pembelajaran Problem Based Learning terhadap kemampuan pemecahan masalah matematika siswa SD. 
1123 Efektivitas Model Problem Based Learning terhadap Kemampuan Pemecahan Masalah Matematika Siswa Sekolah Dasar - Riski Tri Widyastuti, Gamaliel Septian Airlanda

DOI : https://doi.org/10.31004/basicedu.v5i3.896

Effect size dihitung untuk mencari besar pengaruh yang ditimbulkan dari diterapkannya model pembelajaran berbasis masalah (PBL) terhadap kemampuan peserta didik dalam menyelesaikan dan memecahkan masalah khususnya matematika, berikut rumus perhitungan effect size :

$$
d=\frac{\left(M_{2}-M_{1}\right)}{\sqrt{\frac{S D 1^{2}+S D 2^{2}}{2}}}
$$

Keterangan :

d

= Effect Size / besaran efek

Mean $_{1} \quad=$ rata-rata nilai pretest

Mean $_{2} \quad=$ rata-rata nilai posttest

SD1 = Standar deviasi pretest

SD2 = Standar deviasi posttest

Tabel 1. Interpretasi Effect Size

\begin{tabular}{|c|c|}
\hline Effect Size & Interpretasi \\
\hline $0<\mathrm{d}<0,2$ & Kecil \\
\hline $0,2<\mathrm{d} \leq 0,5$ & Sedang \\
\hline $0,5<\mathrm{d} \leq 0,8$ & Besar \\
\hline $\mathrm{d}>0,8$ & Sangat Besar \\
\hline
\end{tabular}

\section{HASIL DAN PEMBAHASAN}

Penelitian metaanalisis yang dilakukan oleh peneliti bertujuan untuk mengetahui pengaruh model pembelajaran Problem Based Learning terhadap kemampuan pemecahan masalah matematika siswa Sekolah Dasar dengan menggunakan metode meta-analisis. Penelitian dilakukan dengan menghitung besar pengaruh (Effect Size) sehingga penulis dapat melakukan pemetaan dan menganalisis efek penerapan model pembelajaran Problem Based Learning dalam pembelajaran khususnya pada kemampuan pemecahan masalah siswa SD. Effect size menunjukkan besar pengaruh dari suatu perlakuan terhadap yang diberlakukan atau dapat dikatakan bahwa effect size menunjukkan hubungan antara dua variabel dalam hal ini variabel bebas yang diteliti adalah model pembelajaran Problem Based Learning, sedangkan variabel terikatnya adalah kemampuan pemecahan masalah matematika siswa SD. Dengan menentukan effect size dari setiap penelitian, maka peneliti dapat menemukan dan menentukan besar pengaruh suatu perlakuan. Peneliti memperoleh hasil penelitian dengan cara mengumpulkan 20 artikel yang memiliki fokus pembahasan yang sama yaitu pengaruh model pembelajaran Problem Based Learning terhadap kemampuan pemecahan masalah matematika siswa Sekolah Dasar. Artikel yang telah diperoleh peneliti kemudian dianalisa untuk memperoleh informasiinformasi inti yang terkait dengan penelitian metaanalasis, kemudian data yang telah diperoleh dihitung menggunakan SPSS dengan tujuan menyajikan kembali hasil perhitungan 20 artikel sejenis tersebut, data yang telah diperoleh kemudian disajikan kembali secara mendeskripsikannya secara kualitatif maupun kuantitatif. Artikel yang dianalisis didapatkan melalui jurnal online/elektronik yang terbit pada tahun 20122020. Berikut data hasil analisis model Problem Based Learning terhadap kemampuan pemecahan masalah matematika siswa Sekolah Dasar : 
1124 Efektivitas Model Problem Based Learning terhadap Kemampuan Pemecahan Masalah Matematika Siswa Sekolah Dasar - Riski Tri Widyastuti, Gamaliel Septian Airlanda

DOI : https://doi.org/10.31004/basicedu.v5i3.896

Tabel 2. Presentase Peningkatan Kemampuan Pemecahan Masalah Matematika Siswa SD

\begin{tabular}{|c|c|c|c|c|}
\hline \multirow[t]{2}{*}{ Kode Data } & \multicolumn{2}{|c|}{$\begin{array}{l}\text { Peningkatan Kemampuan } \\
\text { Matematika Siswa SD }\end{array}$} & Pemecahan Masalah & \multirow[b]{2}{*}{ Gain \% } \\
\hline & Semula & Sesudah & Gain & \\
\hline $\mathrm{X} 1$ & 69,43 & 81,50 & 12,07 & 17,38 \\
\hline $\mathrm{X} 2$ & 60,83 & 84,17 & 23,34 & 38,37 \\
\hline $\mathrm{X} 3$ & 49,15 & 63,19 & 14,04 & 28,57 \\
\hline $\mathrm{X} 4$ & 49,78 & 75,66 & 25,88 & 51,99 \\
\hline $\mathrm{X} 5$ & 41,33 & 61,77 & 20,44 & 49,46 \\
\hline X6 & 67,32 & 81,23 & 13,91 & 20,66 \\
\hline $\mathrm{X} 7$ & 30,41 & 62,8 & 32,39 & 106,51 \\
\hline $\mathrm{X} 8$ & 63,50 & 84,25 & 20,75 & 32,68 \\
\hline X9 & 27,39 & 43,48 & 15,89 & 58,01 \\
\hline $\mathrm{X} 10$ & 71,20 & 81,25 & 10,05 & 14,12 \\
\hline $\mathrm{X} 11$ & 60,25 & 68,61 & 8,36 & 13,88 \\
\hline $\mathrm{X} 12$ & 49,15 & 63,19 & 14,04 & 28,57 \\
\hline $\mathrm{X} 13$ & 66 & 83,54 & 17,54 & 26,58 \\
\hline $\mathrm{X} 14$ & 14,87 & 35,13 & 20,26 & 136,25 \\
\hline $\mathrm{X} 15$ & 75 & 82 & 7 & 9,33 \\
\hline $\mathrm{X} 16$ & 56,42 & 75,52 & 19,1 & 33,85 \\
\hline $\mathrm{X} 17$ & 57,56 & 79,69 & 22,13 & 38,45 \\
\hline $\mathrm{X} 18$ & 65,14 & 73,32 & 8,18 & 12,56 \\
\hline X19 & 34,68 & 39,5 & 4,82 & 13,9 \\
\hline $\mathrm{X} 20$ & 69,03 & 80,97 & 11,94 & 17,3 \\
\hline Mean & 53,92 & 70,04 & 16,11 & 37,42 \\
\hline
\end{tabular}

Berdasarkan tabel 2 diatas adalah data peningkatan kemampuan pemecahan masalah matematis siswa sekolah dasar saat dibelajarkan dengan menggunakan model pembelajaran berbasis masalah (PBL). Presentase terendah kelompok siswa dalam aspek kemampuan penyelesaian masalah matematika saat diberlakukan model pembelajaran berbasis masalah (PBL) adalah 9,33\%, kemudian presentase tertinggi sebesar $136,25 \%$ dan rata-rata sebesar $37,42 \%$. Nilai rata-rata peserta didik dalam aspek penyelesaian masalah matematika sebelum menggunakan model pembelajaran berbasis masalah (PBL) sebesar 53,92\%. Kemudian, nilai rata-rata peserta didik dalam aspek penyelesaian masalah matematika setelah diterapkan model pembelajaran berbasis masalah (PBL) sebesar 70,04\%. Berdasarkan hasil tersebut menunjukkan bahwa nilai rata-rata peserta didik dalam aspek penyelesaian/pemecahan masalah matematika mengalami kenaikan presentase sebesar $37,42 \%$. Hal ini ditunjukan dari hasil analisis uji beda.

Tabel 3. Paired Samples Statistics

\begin{tabular}{|l|l|r|r|r|r|}
\hline & & \multicolumn{1}{|c|}{ Mean } & \multicolumn{1}{c|}{ N } & \multicolumn{1}{c|}{ Std. Deviation } & \multicolumn{1}{c|}{ Std. Error Mean } \\
\hline Pair 1 & Pre_Test & 53.9220 & 20 & 16.59914 & 3.71168 \\
\hline & Post_Test & 70.0385 & 20 & 15.33414 & 3.42882 \\
\hline
\end{tabular}


1125 Efektivitas Model Problem Based Learning terhadap Kemampuan Pemecahan Masalah Matematika Siswa Sekolah Dasar - Riski Tri Widyastuti, Gamaliel Septian Airlanda

DOI : https://doi.org/10.31004/basicedu.v5i3.896

Tabel 3 diatas menunjukkan hasil bahwa pembelajaran dengan menggunakan Model Pembelajaran Problem Based Learning (PBL) mampu meningkatkan kemampuan pemecahan masalah matematika siswa hal ini ditunjukkan dari nilai rata-rata sebelum menerapkan model pembelajaran Problem Based Learning (PBL) sebesar 53,9220 dan setelah diterapkannya model pembelajaran berbasis masalah atau Problem Based Learning nilai rata-ratanya meningkat menjadi 70,0385 artinya model pembelajaran Problem Based Learning mampu meningkatkan kemampuan pemecahan masalah matematika siswa sebesar 16,1165.

Tabel 4. Paired Samples Corelations

\begin{tabular}{|l|l|r|r|r|}
\hline & & N & Correlation & \multicolumn{2}{|c|}{ Sig. } \\
\hline Pair 1 & Pre_Test \& Post_Test & 20 & .907 & .000 \\
\hline
\end{tabular}

Hasil tabel 4 menunjukkan ada relasi atau hubungan antara nilai rata-rata hasil kemampuan pemecahan masalah matematika siswa SD sebelum pembelajaran menggunakan model pembelajaran berbasis masalah (PBL) dan sesudah kelas diterapkan model pembelajaran berbasis masalah (PBL). Hasil uji hipotesis, Ho= tidak terdapat perbedaan yang berarti terhadap hasil kemampuan pemecahan masalah matematika siswa sebelum pembelajaran dengan model pembelajaran berbasis masalah $(\mathrm{PBL})$, sedangkan untuk $\mathrm{H} 1=$ terdapat perbedaan yang berarti hasil kemampuan pemecahan masalah matematika siswa sebelum pembelajaran dengan menerapkan model pembelajaran berbasis masalah (PBL) dan sesudah menerapkan pembelajaran model pembelajaran berbasis masalah (PBL) dari tabel 3 tampak bahwa nilai Sig $(0,00)<\alpha(0,05)$.

Tabel 5. Paired Samples Test

\begin{tabular}{|c|c|c|c|c|c|c|c|c|c|}
\hline & & \multicolumn{5}{|c|}{ Paired Differences } & & & \\
\hline & & & & & $\begin{array}{r}95 \% \mathrm{Cc} \\
\text { interva } \\
\text { Diffe }\end{array}$ & $\begin{array}{l}\text { nfidence } \\
\text { l of the } \\
\text { rence }\end{array}$ & & & \\
\hline & & Mean & $\begin{array}{c}\text { Std. } \\
\text { Deviation }\end{array}$ & $\begin{array}{l}\text { Std Error } \\
\text { Mean }\end{array}$ & Lower & Upper & $\mathrm{t}$ & df & $\begin{array}{l}\text { Sig.(2- } \\
\text { tailed) }\end{array}$ \\
\hline Pair 1 & $\begin{array}{l}\text { Pre_Test- } \\
\text { Post_Test }\end{array}$ & -16.11650 & 7.01404 & 1.56839 & -19.39917 & -12.83383 & 10.276 & 19 & .000 \\
\hline
\end{tabular}

Tabel 5 menunjukkan bahwa nilai t hitung $=10,276>\mathrm{t}$ tabel $=2.093$, maka hasil menunjukkan bahwa Ho ditolak. Sehingga dapat disimpulkan bahwa terdapat perbedaan yang signifikan hasil kemampuan pemecahan masalah matematika siswa Sekolah Dasar sebelum pembelajaran dengan menggunakan model pembelajaran Problem Based Learning dan sesudah pembelajaran dengan menggunakan model pembelajaran Problem Based Learning.

Mean skor hasil belajar sesudah penggunaan model pembelajaran Problem Based Learning lebih tinggi (lebih baik) dari pada sebelum penggunaan model pembelajaran Problem Based Learning. Hal itu diperlihatkan pada tabel Paired Sample Statistics, di mana Mean skor hasil kemampuan pemecahan masalah matematika sebelum penggunaan model pembelajaran Problem Based Learning adalah sebesar 53,9220 sedangkan mean skor hasil kemampuan pemecahan masalah matematika sesudah penggunaan model pembelajaran pembelajaran Problem Based Learning adalah sebesar 70,0385. Artinya, bahwa penggunaan model pembelajaran pembelajaran Problem Based Learning memiliki pengaruh positif yang cukup besar dan signifikan. Untuk menyimpulkan secara keseluruhan pengaruh dari penerapan model pembelajaran Problem Based Learning terhadap kemampuan pemecahan masalah matematika siswa sekolah dasar maka langkah terakhir adalah menghitung nilai effect size, berikut hasil perhitungan nilai effect size : 
1126 Efektivitas Model Problem Based Learning terhadap Kemampuan Pemecahan Masalah Matematika Siswa Sekolah Dasar - Riski Tri Widyastuti, Gamaliel Septian Airlanda

DOI : https://doi.org/10.31004/basicedu.v5i3.896

$d=\frac{\left(M_{2}-M_{1}\right)}{\sqrt{\frac{S D 1^{2}+S D 2^{2}}{2}}}$

Keterangan :

Mean $_{1} \quad=$ rata-rata nilai pretest

Mean $_{2} \quad=$ rata-rata nilai posttest

SD1 $\quad=$ Standar deviasi pretest

SD2 = Standar deviasi posttest

$d=\frac{(70,0385-53,922)}{\sqrt{\frac{16,59914^{2}+15,33414^{2}}{2}}}$

$d=\frac{16,1165}{\sqrt{\frac{275,5314487+235,1358495}{2}}}$

$d=\frac{16,1165}{\sqrt{\frac{510,6672983}{2}}}$

$d=\frac{16,1165}{15,9791614}$

$d=1,009$

Berdasarkan hasil perhitungan yang telah dilakukan oleh peneliti menggunakan rumus uji effect size diatas skor yang diperoleh sebesar 1,009 yang menunjukan bahwa hasil yang diperoleh lebih besar dari 0,8 yang apabila dilihat dari Tabel 1. Interpretasi Effect Size nilai yang lebih besar daripada 0,8 artinya masuk dalam kategori sangat besar. Sehingga dapat disimpulkan bahwa model pembelajaran Problem Based Learning memiliki pengaruh yang besar terhadap kemampuan pemecahan masalah matematika siswa sekolah dasar.

Hasil Output Paired-Sample T Test pada Tabel 3 menunjukkan bahwa model pembelajaran Problem Based Learning dapat meningkatkan kemampuan pemecahan masalah matematika siswa Sekolah Dasar dengan nilai rata-rata 53,9220 menjadi 70,0385. Kemudian pada Tabel 4 terlihat bahwa adanya relasi antara hasil kemampuan pemecahan masalah matematika rata-rata sebelum dengan sesudah menerapkan model pembelajaran Problem Based Learning sebesar 0,907. Hasil uji hipotesis, H0 = tidak terdapat perbedaan yang signifikan kemampuan pemecahan masalah matematika siswa sebelum pembelajaran menggunakan model pembelajaran Problem Based Learning dan $\mathrm{H1}$ = terdapat perbedaan yang signifikan kemampuan pemecahan masalah matematika siswa sebelum pembelajaran menggunakan model pembelajaran Problem Based Learning. Tabel 5 menunjukkan nilai Sig. (2-tailed) $(0,000) \& 1 t ; \alpha(0,05)$ dan thitung $=-10,276$ ttabel $=2.093$ 
1127 Efektivitas Model Problem Based Learning terhadap Kemampuan Pemecahan Masalah Matematika Siswa Sekolah Dasar - Riski Tri Widyastuti, Gamaliel Septian Airlanda

DOI : https://doi.org/10.31004/basicedu.v5i3.896

sehingga Ho di tolak. Jadi, dapat disimpulkan bahwa terdapat perbedaan yang signifikan kemampuan pemecahan masalah matematika siswa sekolah dasar antara yang menggunakan model pembelajaran Problem Based Learning dengan model kelas konvensional.

Berdasarkan hasil perhitungan diperoleh hasil besaran Effect Size sebesar 1,009 dan dapat dilihat dari Tabel 1. Interpretasi Effect Size bahwa model Pembelajaran Problem Based Learning berpengaruh sangat besar pada pembelajaran matematika sekolah dasar karena nilai 1,009>0,8 dalam tabel Tabel 1. Interpretasi Effect Size masuk dalam kategori sangat besar. Problem Based Learning adalah salah satu model pembelajaran yang melibatkan partisipasi siswa secara langsung dalam memecahkan masalah dengan awal pembelajaran yaitu menyajikan terlebih dahulu masalah kontekstual kemudian dipecahkan melalui penyelidikan (Ngalimun, 2013). Sejalan dengan (Ejin, 2016) yang menyatakan bahwa Problem Based Learning adalah model pembelajaran dimana siswa dihadapkan pada masalah kehidupan nyata (kontekstual) dari lingkungan sehingga dapat meningkatkan kemampuan pemahaman konsep dan berpikir kritis siswa. Berdasarkan pendapat yang telah dikemukakan diatas dapat disimpulkan bahwa model pembelajaran Problem Based Learning merupakan salah satu model pembelajaran yang dapat meningkatkan kemampuan pemecahan masalah matematika karena dalam prosesnya siswa dihadapkan pada masalah konkrit dalam kehidupan seharihari (kontekstual) terbukti dari adanya penelitian-penelitian yang membahas pengaruh model pembelajaran Problem Based Learning terhadap kemampuan pemecahan masalah matematika siswa SD, dari 20 jurnal yang dianalisis terbukti bahwa penerapan model pembelajaran model pembelajaran Problem Based Learning memiliki pengaruh yang signifikan dengan peningkatan rata-rata sebesar $37,42 \%$.

Hasil penelitian ini diperkuat dengan penelitian lain yang telah dilakukan (Ermawati, 2020) dengan hasil penelitiannya thitung $(3,801)>$ ttabel $(1,672)$ sehingga Ho ditolak dan Ha diterima. Dengan demikian menunjukkan bahwa adanya perbedaan yang signifikan antara penggunaan model pembelajaran Problem Based Learning dengan konvensional. Penelitian lain sejenis juga dilakukan oleh (Juliawan et al., 2016) yang mengatakan bahwa model Problem Based Learning (PBL) memiliki dampak baik yang signifikan terhadap kemampuan pemecahan masalah matematika siswa kelas III di Gugus III Kecamatan Sukasada, Kabupaten Buleleng Tahun Pelajaran 2016/2017 , dengan hasil penelitiannya t hitung 15,76 > t tabel 2,021. Berdasarkan temuan dari kedua peneliti tersebut terdapat kesamaan yaitu hasil dari $t$ hitung lebih besar daripada $t$ table $(\mathrm{t}$ hitung > t tabel), jika hasil $\mathrm{t}$ hitung lebih besar daripada $\mathrm{t}$ tabel maka $\mathrm{HO}$ ditolak sedangkan Ha diterima. Berdasarkan analisis yang dilakukan oleh peneliti , peneliti sendiri mendapatkan hasil nilai thitung $=10,276$ > $\mathrm{t}$ tabel $=2.093$ yang artinya , maka hasil menunjukkan bahwa Ho ditolak. Sehingga dapat disimpulkan bahwa terdapat perbedaan yang signifikan hasil kemampuan pemecahan masalah matematika siswa Sekolah Dasar sebelum pembelajaran dengan menggunakan model pembelajaran Problem Based Learning dan sesudah pembelajaran dengan menggunakan model pembelajaran Problem Based Learning.

Berdasarkan hasil temuan peneliti serta beberapa peneliti terdahulu menunjukkan bahwa model Problem Based Learning dapat meningkatkan kemampuan pemecahan masalah matematika siswa sekolah dasar karena model PBL merupakan salah satu model pembelajaran yang merangsang partisipasi siswa secara aktif dan kreatif dalam menghadapi masalah kontekstual yang biasa terjadi dalam kehidupan sehari. Penelitian ini masih terdapat beberaapa keterbatasan seperti : kurangnya guru yang mampu mengelola kelas dengan menggunakan model pembelajaran berbasis masalah (PBL), tidak semua anak bersikap aktif dalam pembelajaran sehingga diperlukan usaha ekstra untuk membuat peserta didik aktif berpartisipasi dalam kelas , penerapan model Problem Based Learning (PBL) membutuhkan waktu yang cukup lama dalam pembelajaran karena peserta didik menggali sendiri konsep baru menggunakan pengetahuannya sen diri. 
1128 Efektivitas Model Problem Based Learning terhadap Kemampuan Pemecahan Masalah Matematika Siswa Sekolah Dasar - Riski Tri Widyastuti, Gamaliel Septian Airlanda

DOI : https://doi.org/10.31004/basicedu.v5i3.896

\section{KESIMPULAN}

Simpulan Berdasarkan hasil perhitungan yang telah dilakukan oleh peneliti menunjukkan hasil bahwa salah satu model pembelajaran yang termuat dalam kurikulum 2013 yaitu Problem Based Learning sangat efektif saat diterapkan dalam proses pembelajaran salah satunya dalam hal kemampuan pemecahan masalah matematika siswa sekolah dasar dibanding dengan pelaksanaan proses pembelajaran yang menggunakan model konvensional. Pernyataan ini di dukung berdasarkan hasil perhitungan yang telah dilakukan oleh peneliti, hasil kenaikan skor rata-rata yaitu dari 53,9220 menjadi 70,0385, selanjutnya berdasarkan hasil uji-T nilai $\mathrm{t}$ hitung $=-10,276<\mathrm{t}$ tabel $=2.093$, maka hasil menunjukkan bahwa Ho ditolak. Ho ditolak dapat disimpulkan bahwa terdapat perbedaan yang signifikan hasil kemampuan pemecahan masalah matematika siswa sekolah dasar sebelum pembelajaran dengan menerapkan model pembelajaran Problem Based Learning dengan sesudah pembelajaran dengan menggunakan model pembelajaran Problem Based Learning. Kesimpulan final yang didapatkan oleh peneliti kuncinya adalah pada hasil perhitungan besaran efek (Effect Size) karena dengan melihat nilai besaran efek maka dapat diambil kesimpulan secara keseluruhan tentang pengaruh model pembelajaran berbasis masalah (PBL), peneliti mendapatkan hasil effect size sebesar 1,009 dan dapat dilihat dari Tabel 1. Interpretasi Effect Size bahwa model Pembelajaran Problem Based Learning (PBL) memiliki pengaruh sangat besar pada pembelajaran matematika jenjang sekolah dasar khususnya dalam hal kemampuan pemecahan masalah implikasi yang didapat adalah bahwa model pembelajaran berbasis masalah (PBL) dapat dijadikan referensi bagi guru dalam kegiatan pembelajaran yang berguna untuk merangsang peserta didik untuk berperan aktif dalam kelas serta mampu membiasakan peserta didik untuk terbiasa dalam menghadapi dan menyelesaikan suatu masalah.

Saran yang disampaikan peneliti dalam penelitian ini adalah guru dalam melaksanakan kegiatan proses belajar mengajar dapat menerapkan salah satu model pembelajaran yang termuat dalam kurikulum 2013 yang salah satunya adalah model pembelajaran Problem Based Learning sebagai alternatif dalam mengajar , karena Problem Based Learning merupakan salah satu model pembelajaran yang mengajak siswa untuk berpartisipasi secara aktif untuk menggali sendiri ide, gagasan maupun konsep baru menggunakan pengetahuannya sendiri. Selain itu dalam model pembelajaran Problem Based Learning menyajikan masalah-masalah nyata dalam kehidupan sehari-hari sehingga model ini sangat cocok apabila diterapkan guna meningkatkan kemampuan pemecahan masalah matematika siswa sekolah dasar, dalam hal ini guru harus merangsang siswa untuk terlibat penuh dalam proses pembelajaran, guru berperan sebagai pembimbing dan fasilitator sehingga guru tidak serta merta langsung memindahkan pengetahuan yang dimilikinya kepada siswa menggunakan cara tradisional melainkan guru melakukan proses mengajar dengan cara mengajak siswa untuk berpikir tingkat tinggi supaya terbiasa dalam hal memecahkan masalah dalam kehidupan sehari-hari. Partisipasi langsung dari siswa diharapkan mampu membuat siswa terbiasa dalam menghadapi masalah dan mencari jalan keluar akan permasalahan tersebut.

\section{UCAPAN TERIMA KASIH}

Rasa terima kasih yang sebesar-besarnya peneliti ucapkan kehadirat Allah SWT yang telah memberikan kelancaran dalam menyelesaikan artikel ini. Selain itu rasa terima kasih juga kepada orang tua yang senantiasa memberi dukungan secara moral untuk peneliti agar tidak putus asa dalam melakukan penelitian. Tak lupa terima kasih kepada dosen pembimbing peneliti yaitu bapak Gamaliel Septian Airlanda, S.Pd , M.Pd. yang telah memberi arahan dan juga masukan dalam menyelesaikan penelitian ini. 
1129 Efektivitas Model Problem Based Learning terhadap Kemampuan Pemecahan Masalah Matematika Siswa Sekolah Dasar - Riski Tri Widyastuti, Gamaliel Septian Airlanda

DOI : https://doi.org/10.31004/basicedu.v5i3.896

\section{DAFTAR PUSTAKA}

Anugraheni, I. (2018). Meta analisis model pembelajaran problem based learning dalam meningkatkan keterampilan berpikir kritis di sekolah dasar. Polygot, 14(1), 9-18.

http://dx.doi.org/10.19166/pji.v14i1.789

Aqil, Z. (2013). Model-Model, Media, Dan Strategi Pembelajaran Kontekstual(Inovatif). Yrama Widya.

Ejin, S. (2016). Pengaruh Model Problem Based Learning (PBL)Terhadap Pemahaman Konsep dan Keterampilan Berpikir Kritis Siswa Kelas IV SDN Jambu Hilir Baluti 2 Pada Mata Pelajaran Ilmu Pengetahuan Alam. Jurnal Pendidikan.

Ermawati, D. (2020). PENGARUH PROBLEM BASED LEARNING DENGAN METODE DEMONSTRASI TERHADAP KEMAMPUAN PEMECAHAN.

Ertikanto, C. (2016). Teori Belajar Dan Pembelajaran. Media Akademi.

Juliawan, G. A., Mahadewi, L. P. P., \& Rati, W. R. (2016). Pengaruh Model Problem Based Learning (PBL) Terhadap Kemampuan Pemecahan Masalah Matematika. Jurnal Pendidikan Sains, 4(2), 60-64.

Kadir. (2017). Meta-Analysis of the Effect of Learning Intervention Toward Mathematical Thinking on Research and Publication of Students Tarbiya. Journal of Education in Muslim Society.

KEMENDIKBUD. (2013). Permendikbud Nomor 65 Tahun 2013 Tentang Standar Proses. 2011, 1-13.

Kodariyati, L., \& Astuti, B. (2016). Pengaruh Model Pbl Terhadap Kemampuan Komunikasi Dan Pemecahan Masalah Matematika Siswa Kelas V Sd. Jurnal Prima Edukasia, 4(1), 93. https://doi.org/10.21831/jpe.v4i1.7713

Nasir, M. (2016). Efektivitas Model Pembelajaran Berbasis Masalah ( Problem Based Learning ) Terhadap Kemampuan Pemecahan Masalah Siswa Pada Pelajaran Matematika. Madrasah Ibtidaiyah, 1(2):1-19.

Ngalimun. (2013). Strategi Dan Model Pembelajaran. Aswaja Pressindo.

Putri, U. A. (2020). Efektivitas Model Problem Based Learning Dan Problem Solving Ditinjau Dari Kemampuan Pemecahan Masalah Matematika Peserta Didik Kelas IV SD. Jurnal Edukasi Matematika Dan Sains. https://doi.org/10.25273

Sapoetra, Bagoes Pradana, dan A. T. A. H. (2020). Efektivitas Model Pembelajaran Problem Based Learning Ditinjau Dari Kemampuan Pemecahan Masalah Matematika Di Sekolah Dasar. Jurnal Basicedu 4(4):1044-51.

Slameto. (2013). Belajar Dan Faktor-faktor Yang Mempengaruhi. Rineka Jaya.

Susanto, A. (2014). Teori Belajar \& Pembelajaran di Sekolah Dasar. Kencana Prenamedia Group. 